\title{
Diagnosis and management of miliary tuberculosis: current state and future perspectives [Retraction]
}

\author{
Ray S, Talukdar A, Kundu S, Khanra D, Sonthalia N. Diagnosis \\ and management of miliary tuberculosis: current state and \\ future perspectives. Ther Clin Risk Mngmt. 2013;9:9-26.
}

The editor of the Indian Journal of Medical Research has brought to our attention the unacknowledged re-use of significant portions of text in the above article. The source of much of the text appears to be from:

Sharma SK, Mohan A, Sharma A. Challenges in the diagnosis and treatment of miliary tuberculosis. Indian J Med Res. 135, May 2012, pp 703-730.
Dr Ray comments thus:

"Regarding the similarities found we want to clarify that this apparent plagiarism is not an intentional act and likely to be factual error. In any way, we do not want to undermine scientific pursuit or vitiate the investigational spirit of hard work and creativity. Please be informed that the different portions of the review were written by different co-authors and most of them were postgraduate students at that time. It seems that they have taken materials/ideas from previously published source unaware of the issues of plagiarism."

\section{Publish your work in this journal}

Therapeutics and Clinical Risk Management is an international, peerreviewed journal of clinical therapeutics and risk management, focusing on concise rapid reporting of clinical studies in all therapeutic areas, outcomes, safety, and programs for the effective, safe, and sustained use of medicines. This journal is indexed on PubMed Central, CAS,
EMBase, Scopus and the Elsevier Bibliographic databases. The manuscript management system is completely online and includes a very quick and fair peer-review system, which is all easy to use. Visit http://www.dovepress.com/testimonials.php to read real quotes from published authors. 